\title{
The interplay between stakeholders, resources and capabilities in climate change strategy: converting barriers into cooperation
}

Ana Beatriz Lopes de Sousa Jabbour, Montpellier Business School, France.

Diego Vazquez-Brust, University of Portsmouth, UK;

Daniela Adriani Ribeiro

Sao Paulo State University, Brazil

Charbel Jose Chiappetta Jabbour; corresponding author Montpellier Business School, France cjc-jabbour@montpellier-bs.com

\begin{abstract}
This article investigates how organizations deal with drivers and barriers to the adoption of low-carbon operational (LCO) practices and, accordingly, we propose a framework for relationships with stakeholders to guide organizations in orchestrating stakeholders, resources and capabilities to meet the challenges and opportunities arising from climate change. Data was collected through interviews with experts working within companies participating in the Carbon Disclosure Program and the Brazilian GHG Protocol Program. Our findings show that the level of willingness of stakeholders influences how companies select mechanisms to deal with drivers and barriers to LCO practices. Our results, qualified by stakeholder relationships theory and the natural resource-based view, introduce an analytical approach called 'mechanisms of responses' to understand how organizations deal with drivers and barriers in the context of climate change in order to guide companies to adopt LCO practices, strengthen co-operation with stakeholders and develop the required organizational capabilities.
\end{abstract}

Keywords: Corporate sustainability, climate change, business strategy, barriers, drivers. 


\section{Introduction}

Climate change has emerged as a major management issue to be dealt with by society in the next 20 years (Shaw et al., 2018). Business leaders have come to recognize the urgency of tackling climate change. Nevertheless, according to a recent survey conducted with 1,000 global executives by Accenture and the UN Global Compact, only $35 \%$ of the CEOs interviewed deploy or plan to set a carbon target within the next year, less than the figure of $43 \%$ when this same survey was conducted three years ago (Winston, 2019).

Companies will be required to decarbonize their operations in order to act against climate change (Pinner and Sneader, 2019) through the adoption of low-carbon operational (LCO) practices, which involves designing, planning and controlling manufacturing operations and logistics (Childe, 2007) aiming to minimize resource consumption, waste and carbon emissions.

According to an article published by PwC (2016), stakeholders have begun to request that companies provide information on the risks resulting from climate change to assist in their decision-making. For this reason, it is necessary for organizations to respond to stakeholders' expectations, by formulating and implementing processes that satisfy them (Freeman and Mc Vea, 2001), such as LCO practices.

Collaboration in multi-stakeholder partnerships must be scaled up in order to accelerate the transition to climate-friendly business models, but many firms do not have the capabilities required to successfully engage stakeholders in these partnerships (Pinkse and Busch, 2013). Organizations require appropriate capabilities and resources to develop strategies that meet the demands of stakeholders in adopting LCO practices. However, if organizations do not have adequate resources and capabilities for the deployment of LCO practices, resources and capabilities become barriers rather than drivers for the adoption of LCO practices. In the same vein, stakeholders can, dependent on their standing, represent either barriers or motivators for organizations' adoption of LCO practices (Wood et al., 2018). Thus, it is important to understand how companies deal with the barriers and drivers represented by stakeholders, resources and capabilities.

Understanding the barriers to the adoption of LCO practices, as well as the organizational mechanisms available to deal with them, could help businesses set out strategic actions to adapt to climate change (Biesbroek et al., 2013; Biesbroek et al., 2013; Eisenack et al., 2014). This aligns with the perception of CEOs, outlined in documents 
from Accenture and the UN Global Compact, who suggest that it is crucial to approach barriers effectively, applying solutions to reduce these barriers in combating climate change (Accenture \& United Nations Global Compact, 2019).

However, the current scientific debate on corporate responses to climate change focuses mainly on identifying corporate response typologies (e.g. Sakhel, 2017; Herrmann and Guenther, 2017; Lee, 2012; Weinhofer and Hoffmann, 2010), and examining corporate responses as a result of stakeholder pressure (e.g. Cadez et al., 2019; Pesonen and Horn, 2014; Pinkse and Busch, 2013, Sprengel and Busch, 2011). A few studies analyze the development of organizational capabilities and the role of stakeholders in the context of the low-carbon economy (Heikkinen, 2017, Baranova and Meadown, 2017, Kolk and Pinkse, 2008). To date, studies have failed to address the plea of CEOs surveyed by Accenture and the UN, which states that 'it is necessary to know how to approach the barriers to actions against climate change, and how solutions get implemented' (Accenture, 2019).

In this context, this research aims to extend the current state of knowledge on corporate responses to climate change, investigating how organizations deal with the drivers of, and barriers to, the adoption of LCO practices. In order to achieve this, an analytical approach called 'mechanisms of responses' is used to evaluate how the surveyed companies deal with the barriers and drivers arising from stakeholders, resources and capabilities. As a result of the identification of the mechanisms behind the company responses, a framework based on the level of willingness of stakeholders to cooperate with climate change issues is proposed. This framework is grounded in the typology developed by Savage et al. (1991), which outlines strategies for managing stakeholders with different levels of potential for cooperation.

We draw on case studies of large Brazilian companies to propose a framework that will guide organizations in orchestrating stakeholders, resources and capabilities to meet the challenges and opportunities arising from climate change management.

Developing countries are both more exposed to the challenges of climate change and less prepared to mitigate them (The Economist, 2018; IPCC, 2014). Thus, Brazilian companies were studied in order to highlight the reality of developing countries, which are likely to encounter more barriers in their fight against the issues presented by climate change. Brazil has proposed to reduce its greenhouse gas emissions by $37 \%$ by 2020 as part of the COP 21 agreement (Marcondes and Canto, 2015). This is a bold aim for a 
developing country, suggesting that Brazil is determined to decrease its carbon emissions. Brazil's contextual features must be considered in order to understand the barriers and drivers at work in the struggle against climate change.

The theoretical contribution of this article is based on testing Savage et al.'s stakeholders approach (1991) in a different context (climate breakdown), and combining Savage et al.'s stakeholders approach (1991) with a new analytical approach proposed in this article, called 'mechanisms of responses', to create a managerial framework to guide organizations in orchestrating stakeholders, resources and capabilities to meet the challenges and opportunities arising from climate change management. Therefore, this article seeds ideas for a new perspective on how to manage stakeholders in the fight against climate change. This article represents a unique research frontier in building a new construct, according to Colquitt and Zapata-Phelan's guidelines for theoretical contributions (2007).

The following sections present the theoretical background to stakeholder theory and the natural resource-based view in the context of climate change, as well as discussing drivers and barriers for the adoption of LCO practices to underpin the analytical approach called 'mechanisms of responses.' Section 3 outlines the research methodology procedures; the results are presented in Section 4 and discussed in Section 5, while Section 6 summarizes the findings and contributions.

\section{Theoretical Background}

\subsection{Stakeholder cooperation}

Actions designed to mitigate climate change have become a strategic issue for organizations around the world (Glienke and Guenther, 2016). Often, such actions are implemented due to the demands of stakeholders (Rasi et al., 2014), and engaging stakeholders in the development of responses to climate change is becoming a necessary process (Reyers et al., 2011).

Savage et al. (1991) define four classifications for understanding the role of stakeholders in influencing strategic actions, according to their potential to threaten or cooperate with these actions. These categories are: a) supportive - low potential for threat and high potential for co-operation with the organization, the optimal strategy is to involve them; b) marginal - low potential for both co-operation and threat, the optimal strategy is to monitor them; c) non-supportive - high potential for threat and low potential 
for co-operation, the strategy should be defensive; and d) mixed blessing - high potential for both co-operation and threat, where the recommended strategy is collaboration between the parties. Figure 1 presents this classification system.

Please, Insert Figure 1 here-

Drawing a parallel with the typology posited by Savage et al. (1991), a stakeholder can be a source of either threat or co-operation, meaning they can act as either a motivator or barrier for organizations that want to adopt LCO practices. Therefore, organizations need to strategically manage their relations with stakeholders (Herbohn et al., 2014). However, organizations must also have sufficient resources and capabilities to deal with the impacts of climate change (Gasbarro and Pinkse, 2016), and to adopt strategies to overcome the negative and enhance the positive influences of stakeholders.

The next section considers strategic responses to stakeholder demands.

\subsection{LCO practices as a strategic response to stakeholders: The natural resource-based} view perspective

The control and use of companies' financial, technological and organizational resources is vital in developing effective responses to climate change (Okereke et al., 2012). Perhaps the most important organizational challenge represented by climate change is the need to develop resources and capabilities to deal with the new and significant challenges that climate change presents (Linnenluecke and Griffiths, 2010; Okereke et al., 2012), because climate change demands investment and does not readily results in profit (Goworek et al., 2018).

The resources and capabilities of organizations are addressed in the resourcebased view theory (RBV) (Barney et al., 2011; Hoskisson et al., 1999). RBV defines resources as "all assets, capabilities, organizational processes, firm attributes, information, knowledge, etc. controlled by a firm" (Barney, 1991, p. 101). Capabilities are the abilities endowed by a set of resources to perform some activity or task; this involves co-ordination among people, and between people and other resources (Amit and Schoemaker, 1993).

The natural resource-based view (NRBV) is a theory of competitive advantage based on the relationship between an organization and the natural environment (Hart, 1995). Hart (1995) suggests that an organization can gain competitive advantage through the implementation of environmental strategies, such as: prevention of pollution by 
reducing emissions and process effluents; product management by minimizing the environmental impact of products' life cycles; and sustainable development by minimizing the environmental impact of the organization due to growth and development.

The environmental strategies defined by the NRBV can be used by organizations to mitigate the impacts of climate change. Thus, this theory is related to LCO practices. LCO practices can be divided into the following categories: low-carbon products, lowcarbon production and low-carbon logistics (Böttcher and Müller, 2015).

To develop low-carbon products, companies can switch to products that consume less energy, replace raw materials which have high carbon footprints, and decrease the amount of manufacturing materials used (Wang, 2017). These examples show a convergence with the strategy of product management as defined by Hart (1995). With this in mind, we propose that the development of low-carbon products is directly related to product management strategy.

With regard to low-carbon production, examples of this practice include reduction of energy consumption in production processes, the use of efficient technologies, the reduction of waste disposal and the re-use and recycling of materials (Giesekam et al., 2014; Guoyou et al., 2013; Ng et al., 2013; Rasi et al., 2014). These production practices also fit the strategy for pollution prevention, as this strategy is concerned with production capabilities and operations (Hart, 1995). Thus, we propose that the practice of low-carbon production is directly related to pollution prevention strategy.

To implement low-carbon logistics, it is necessary to know how to measure the performance of logistical operations (He et al., 2017). Organizations can substitute highenergy modes of transport for those that generate less carbon emissions, split transport operations, design optimal transport routes, improve drivers' awareness of prudent driving and use alternative fuels (Martinsen and Huge-Brodin, 2014). As green logistics management can improve the ability of organizations to conserve natural resources, reduce waste and improve operational efficiency, we propose that low-carbon logistics is related to pollution prevention strategy.

While sustainable development strategy (Hart and Dowell, 2011) will not be explored further here, it can be inferred that the three aspects of LCO practice mentioned above all fit with this strategy. 


\subsection{Barriers and drivers for the adoption of LCO and mechanisms of response}

To understand more about barriers and drivers for the adoption of LCO, a systematic review of the literature was performed, involving a search for articles related to the terms 'barriers', 'drivers', 'carbon strategy', 'operations' and 'environment'. This search returned 2,702 articles and, after reading abstracts and texts, resulted in 45 articles which were found to be relevant to the theme (Tables 1 and 2). Barriers and drivers were presented jointly, as there may be aspects that act as both barriers and drivers (Eisenack et al., 2014). Tables 1 and 2 summarize the main drivers and barriers created by stakeholders, resources and capabilities.

Please, Insert Table 1 here

Please, Insert Table 2 here

From Table 1, it is evident that over a third of the variables - drivers and/or barriers - caused by stakeholders originate in the government (e.g. policies, legislation and incentives). Another important stakeholder group is clients, who are the second most cited stakeholder in the articles analyzed. Clients are in a particularly strong position to motivate organizations to adopt green practices (Chu and Schroeder, 2010), but can also act as a barrier by not recognizing these practices (Ng et al., 2013). Suppliers may stand out due to their ability or inability to accurately measure $\mathrm{CO}_{2}$ emissions from their operations (Garbuzova and Madlener, 2012), provide carbon efficient technologies (Ng et al., 2013), adapt to different types of production processes (Eisenack et al., 2014; Jones, 2015) or even provide them (Liu, 2012, 2014).

According to Table 2, the variables that appear most frequently in the relevant studies are 'financial issues', 'information/knowledge' and 'social and environmental responsibility'. Financial issues influence the availability of financial resources for organizations to acquire, implement, and maintain LCO practices. 'Information/knowledge' can facilitate adoption, but can also be a barrier to adoption in the absence of guidelines, policies and regulations. A lack of institutional effort at the national level (Jeswani et al., 2008) or a lack of environmental knowledge may also present barriers. 'Social and environmental responsibility' refers to actions that mitigate the impacts of climate change, in which organizations voluntarily take part, although the existence of tradeoffs between social and environmental responsibilities can become a barrier when there are resource implications, such as time and/or money (Jongh and Mollmann, 2014). 
After highlighting the barriers and drivers for LCO practices, another important aspect to consider is how organizations respond to these barriers and drivers. Previous studies have only superficially addressed these matters; therefore, this article proposes an analytical approach to better understand how organizations can deal with barriers and take advantage of drivers, since, to date, no such system exists. This analytical approach is termed 'mechanisms of response', and is based on risk management and project management concepts (Eisenack et al., 2014; Joia et al., 2013). The risk-based approach has a strong relationship with low-carbon operations management, because it provides a basis for assessing potential opportunities, constraints and limitations associated with decision-making in adaptation to climate change (IPCC, 2014).

Barriers may be accepted, reduced or overcome. If an organization decides to accept barriers, this can take the form of either passive acceptance, in which nothing will be done, or active acceptance, which involves monitoring the barrier due to its dynamic and interdependent features (Eisenack et al., 2014). This strategy should be adopted when it is not possible to eliminate a barrier, or a part of it. For a barrier to be reduced or overcome, it is necessary to compare it with other barriers, understand why related actions are performed in the way they are, and understand the context within which the organization is operating (Eisenack et al., 2014). However, to minimize risk, actions should be focused on reducing the probability and/or impact of such barriers, while also making attempts to overcome or eliminate the root cause of the barrier, thus removing it totally (Joia et al., 2013).

According to Joia et al. (2013), the potential responses to drivers are to accept, improve, or explore them. To accept a driver, an organization need not do anything; it can simply take advantage of it without active involvement. To improve a driver, it must first be identified. The main motivators which increase the probability of its success should then be maximized. In exploring a driver, it is important to stimulate it by taking steps to ensure that the opportunity is realized (Joia et al., 2013). Chart 1 summarizes these mechanisms and actions.

\section{Please, Insert Chart 1 here}

In short, the typical 'accept' response is 'business as usual'; moderate responses ('reduce' or 'improve') represent an incremental change; while 'explore' and 'overcome' are transformational responses. Differences in these mechanisms of response suggest that some organizations have certain resources and capabilities that enable them to cope better 
with barriers than other organizations under similar circumstances (Linnenluecke and Griffiths, 2010).

The integration of stakeholder theory with NRBV suggests that transformational responses require that organizations have specific and sufficient resources and capabilities to develop strategies to overcome the negative and enhance the positive influences in the development of LCO practices among stakeholders and existing resources and capabilities (Garbuzova and Madlener, 2012, Ng et al., 2013, Eisenack et al., 2014; Jones, 2015, Liu, 2012, 2014).

While several existing articles have proposed types of corporate response to climate risk categories (e.g. Sakhel, 2017), they have not identified 'response mechanisms' or discussed the factors that influence how companies deal with drivers and barriers to climate change strategies. Moreover, there is limited understanding of the attributes and circumstances that can make the same stakeholder either a motivator of or an impediment to the adoption of organizational practices. As a consequence, there is not yet enough understanding of how companies can strategically manage their relations with stakeholders in order to turn a potential stakeholder barrier into an opportunity for collaboration in the implementation of LCO practices (Herbohn et al., 2014, 2012). Therefore, our research attempts to address the aforementioned gaps.

\section{Research Methodology}

\subsection{Research method and sample}

The methodological approach chosen for this study comprises interviews with specialists. Due to the nature of the barriers and drivers under consideration, this is a suitable qualitative method, with a basis in the perceptions of informed individuals (Jones, 2015). In addition, interviews with specialists are useful for extracting and analyzing the perceptions of business leaders, who have been closely involved in efforts to develop and implement organizational responses to climate change (Okereke and Kung, 2013). Moreover, this article aims to introduce a new analytical approach called 'mechanisms of responses'; therefore, qualitative research is suitable for capturing the nuances of respondents.

Brazil provides the appropriate contextual and political setting to help understand organizations' decision-making regarding climate change strategies. Brazil launched a National Plan of Adaptation to Climate Change (NPACC) in 2016, which includes 
guidelines for the private sector to adopt climate change adaptation actions (MMA, 2019). This plan may assist firms operating in Brazil to deal with the risks arising from climate change. Research conducted by the Carbon Disclosure Program in Brazil, in 2014, identified that Brazilian firms tend to prioritize short-term actions related to carbon emissions regulation, over investment in long-term solutions. As a result, these Brazilian firms have engaged with policymakers and sector associations in order to manage carbon emissions reporting (CDP, 2014). Therefore, this article brings insights into firms' decision-making regarding stakeholders, to deal with climate change risks in a context where firms are primarily driven by regulatory requirements.

By means of searches conducted on the websites of the Carbon Disclosure Program (CDP) and Brazilian GHG Protocol Program, as well as internet searches for relevant companies which publish sustainability reports, we identified 92 companies located in Brazil which are actively involved in LCO practices. We contacted employees of these companies who work in areas directly responsible for communicating information about inventories of greenhouse gas emissions. Twenty-four individuals agreed to be interviewed.

\subsection{Data collection}

The interviews were conducted based on a script, which was supported by the theoretical framework of this research, and pre-tested in terms of content and complexity by four experts in the climate change field. The questionnaire comprised 21 questions divided into 3 groups, with each group containing 7 questions. The first group concerned low-carbon products, the second low-carbon production and the third low-carbon logistics. For each group, the company was asked about whether it employed LCO practices, to provide examples of the practices adopted, as well as the drivers and barriers to their adoption of LCO practices. The company was also asked to detail how it dealt with each motivation and barrier, and if there were any LCO practices that the company would like to adopt but had not, as well as investigating the reasons for this lack of adoption. The script used in the interviews is available in the Appendix.

Table 3 presents the job roles of the interviewees within the companies studied, while Table 4 shows the number of companies studied by economic sector. These sectors were categorized following the OECD classification system (NACE Rev.2, 2 digits level), which includes high technology products, medium-high technology products, medium- 
low technology products, low technology products, construction and primary industries and knowledge intensive services (e.g. Heidenreich, 2009).

Please, Insert Table 3 here

-Please, Insert Table 4 here

The interviews were conducted in person, either via phone or Skype, according to the preference and availability of each interviewee. Only one employee from each company was interviewed, thus giving a total of 24 interviewees. The interviews took place between May and July 2016, and lasted from 45 minutes to 2 hours and 15 minutes. 21 of the interviews were recorded. In addition, notes were taken during the interviews to record important points, and analyze the data more effectively. Following the completion of the interviews, the recordings were transcribed, as suggested by Rowley (2012).

\subsection{Data analysis}

To analyze the data gathered from the interviews, a method of thematic analysis was chosen as a suitable approach for identifying and analyzing patterns in qualitative data (Clarke and Braun, 2013). The analytical procedures are described below, and are based on Smith's structure (2014).

1. Development of broad descriptions to organize the data gathered

$\checkmark$ Descriptions of each interview/company were based on the transcription of the records, the notes taken during the interviews and some data available from sustainability reports of the companies studied. Twenty-four files were created, containing over 100 pages in total.

$\checkmark$ The descriptions were shared with each interviewee to assess reliability and comprehensiveness, and to obtain the interviewees' approval.

2. Identification of evidence in each case

$\checkmark$ Four themes were created: LCO practices, drivers, barriers that prevent practices being deployed, and difficulties faced during adoption of LCO practices. These themes guided the process of identification of evidence (examples) in each description (in each interview).

$\checkmark$ Two authors of the article read all the descriptions, to become familiar with the content of the interviews and suggest terms which helped to identify evidence regarding the themes. 
$\checkmark$ A list of terms to represent each theme was generated, enabling an easy and systematic search for evidence in each description file.

$\checkmark$ Below are examples of terms utilized for the identification of evidence regarding each theme:

$>$ LCO practices - 'project', 'program', 'action', 'task', 'process', 'product', 'reduction of emissions', 'reuse', 'avoid', 'reduce'.

> Drivers - 'starting', 'motivation', 'cost'.

> Barriers that prevent practices being deployed - 'it wasn't doable', 'barrier', 'difficulty'.

Difficulties faced during adoption of LCO practices - 'limitation', 'it isn't easy', 'deal with', 'conversion'

3. Matching evidence with the literature review

$\checkmark$ Evidence which appeared repeatedly for the theme of LCO practices was identified, and was related to low-carbon products, low carbon processes, and low-carbon logistics. Table 5 shows the results of this identification.

$\checkmark$ Evidence which appeared repeatedly for the themes of drivers, barriers that prevent deployment of practices, and difficulties faced during adoption of LCO practices were identified. These were compared with the salient items from Tables 1 and 2 in order to categorize the main barriers and drivers for LCO practices. Tables 6 and 7 show the results of this process.

$\checkmark$ Based on interviewees' comments on drivers, barriers to practices being deployed, and difficulties faced during adoption of LCO practices, we identified how they dealt with drivers and barriers to LCO practices. After this identification, it was possible to match their methods of dealing with drivers and barriers with the proposed mechanisms of responses (Table 3). Tables 8 and 9 illustrate these results.

Tables 8 and 9 were analyzed in view of the roles of stakeholders, resources and capabilities in enabling or inhibiting organizations adopting LCO practices as strategic responses to climate change. Figures 2 and 3 systematize the research's main insights. Figure 3, in particular, demonstrates Savage et al.'s typology (1991) of stakeholders' potential for cooperation in strategic actions with mechanisms of response to guide managers on how to orchestrate stakeholders, resources and capabilities in order to convert barriers into cooperation. 
The combination of Savage et al.'s classification (1991) with the mechanisms of response is the theoretical contribution of this article, seeding ideas for a new perspective on how to manage stakeholders towards climate change matters. This article is working at the frontier, building a new construct, according to Colquitt and Zapata-Phelan's guidelines (2007) for theoretical contributions. Furthermore, this article employs a qualitative research method, a suitable approach when proposing a new construct.

\section{Results}

The results of the interviews are divided into three categories: adoption of LCO practices, drivers and barriers related to the adoption of these practices, and organizational response mechanisms for these drivers and barriers. The results of each category are presented in tables below that summarize the relevant responses obtained from the interviews, which are then interpreted and discussed.

\subsection{Adoption of LCO practices}

Organizations' adoption of LCO practices is presented in Table 5.

Please, Insert Table 5 here

Regarding low-carbon products, the interviews revealed that the replacement of materials with high carbon footprints and the use of renewable and recyclable materials are perceived as related practices, because renewable inputs tend to have lower carbon footprints.

With regard to low-carbon production, the most commonly mentioned practice was the use of efficient technologies. These technologies enable organizations to consume less electricity in their production and administrative processes. Initiatives cited include the introduction of LED lamps and more efficient use of equipment and machinery.

Meanwhile, low-carbon logistics was explored to a lesser extent than low-carbon products and production. Reasons given for this included:

"Any super investment, any super effort that I do in there, it's going to have a very small representation in my emissions inventory" (Interviewee A).

"We struggle more with our direct emissions, because the effort and the reduction in energy intensive processes are much more significant than with that of logistics" 


\subsection{Drivers and barriers to the adoption of LCO practices}

Tables 6 and 7 report the main barriers and drivers to adopting LCO practices according to the companies studied.

The three stakeholders which stand out as impediments to the adoption of LCO practices are suppliers, government, and clients. The barriers caused by suppliers include the availability and adequacy of efficient technologies, as well as attitudes and relationships with the company. The government acts as a barrier due to its lack of support, or tax incentives for the adoption of LCO practices in companies. Clients act as a barrier because the adoption of LCO practices often inflates the price of products, as a result of which clients may opt for cheaper alternatives without regard for environmental issues.

In terms of resources and capabilities, financial and human resources are the main barriers which hinder a company's adoption of LCO practices. The financial barriers lie in the high initial cost of implementing these practices, which often have a long payoff period. The attitude of employees, whether through resistance, aversion to change or lack of sensitivity to environmental issues, can also act in opposition to the needs of the organization.

\section{Please, Insert Table 6 here-}

Shareholders and owners are the stakeholders who act as drivers, as well as clients concerned about the company's environmental impact. These clients may demand that the company pollutes less, or request companies to invest in products with a lower carbon footprint. These factors encourage companies to differentiate their products and gain a competitive advantage over their competitors.

Financial resources also appear to have a positive influence on the adoption of LCO practices. While the interviewees understand that LCO practices are expensive to implement, they also result in savings for organizations, by promoting energy efficiency in production processes or providing cheaper logistics through optimized transportation of products. Furthermore, it can be concluded that organizational capabilities are very important for the adoption of LCO practices, since the majority of reasons cited by the interviewees relate to capabilities: capabilities for pooling of resources, competitive advantage creation, and social and environmental responsibility. 


\subsection{Mechanisms of response to barriers and drivers for the adoption of LCO practices}

The major insights obtained regarding how the sample studied responds to drivers and barriers to LCO adoption are presented in Tables 8 and 9 and discussed below, in order to better understand the results reported in Tables 6 and 7.

With respect to the organizational responses to barriers to LCO practices, it is evident that companies respond to barriers in two main ways: accepting them and overcoming them. In accepting a barrier, companies do not take any action or assume the costs, even if these are high. When a company does not act, the barrier tends to be associated with highly salient stakeholders who are unwilling or unable to collaborate with the company; for instance, clients who do not encourage or plainly oppose the practice of low-carbon operations (i.e. interviewee $\mathrm{C}$, interviewee $\mathrm{V}$ ), or powerful governmental stakeholders.

Among the companies in this study, overcoming was the most common response to barriers created by resources and capabilities. In particular, this strategy was used extensively in response to the barrier 'attitude and relationship of employees'. Training and raising employee awareness were practices widely used in company $\mathrm{C}$ and several others, in order to change the behavior of employees and to acclimatize them to environmental issues; for instance, company $\mathrm{Z}$ employed consultants as LCO coaches. In addition to training, interviewee $\mathrm{C}$ noted that a top-down orientation reduces employee resistance to the adoption of such practices.

In terms of barriers initiated by suppliers, either through behavior or the unavailability of a technology, the willingness of the stakeholder to collaborate is key. Companies can overcome barriers by working with the stakeholder to engage them in LCO practices through workshops, meetings, and training, working together towards finding a solution where it is feasible to adopt the practice.

\section{Please, Insert Table 8 here}

Regarding responses to drivers, all interviewees went beyond mere 'acceptance' and used 'improve' and 'explore' strategies to deal with their motivators.

The 'improve' response mechanism means that companies increasingly monitor the adoption of LCO practices through audits and inspections. The monitoring processes act as tools that help managers to identify potential and actual mistakes, increase the 
responsibility, commitment, and motivation of employees, and also help to highlight improvements in LCO processes, driving organizations towards competitive advantage.

To explore drivers, companies maintain research and development laboratories that identify best practices and, through stakeholder requirements, are able to develop products and solutions for production and logistics processes, giving organizations advantages over their competitors.

Organizations also align their strategies with sustainability issues and, therefore, issues of low-carbon operations management; through this mechanism, enterprises coordinate and prioritize the low-carbon aspects of their processes in order to meet social and environmental responsibilities.

Companies may invest in LCO practices despite the expense, if the salient internal stakeholders - such as senior management, board members or owners - show an interest in climate change. These companies commit to climate change issues, which in turn means they encourage stakeholders to adopt LCO practices which strengthen their image as a company which is concerned with social and environmental responsibilities.

Another prominent mechanism highlighted in the interviews is defining goals, with participation in profits and enterprise results as well as employee bonuses for achieving goals at various hierarchical levels of an organization. With this mechanism companies can motivate employees to strive for goals which align with the organization's strategic plan.

\section{Please, Insert Table 9 here}

Figure 2 summarizes the main findings of this research, focusing on the response mechanisms that help firms adopt LCO practices.

\section{Please, Insert Figure 2 here}

Our analysis suggests that a company's choice of response mechanism to address barriers and drivers of LCO practices is influenced by the interplay between two dimensions: their assessment of stakeholders' potential to create barriers to the adoption of LCO practices (e.g. government and clients), and their perception of the extent to which stakeholders are willing to cooperate with the company in the implementation of LCO practices (e.g. suppliers). Stakeholders' perceived potential to act as barriers accounts for the extent to which they can derail the implementation of LCO practices, either by withholding resources or by directly opposing LCO action. The government, clients, suppliers and employees are perceived as potential barriers. 
"We cannot take the range of actions that we would like because not only there is not LCO-supportive regulation, but also current policy gives incentives for high carbon economy or forbids some practices that could support LCO operations. Example? Hybrid sourcing (suppliers located within the premises of the factory) can foster LCO logistics, but is forbidden" (Interviewee Y).

"Our marketing department ran a survey and they found that clients would not buy our planned LCO models because the materials with lower carbon footprint make them heavier" (Interviewee X).

"We cannot get the low-carbon products we need, there were no suppliers able to make such investment" (Interviewee V)

"Shareholders are not a barrier for us, there has never been a drop in our shares after pro-environmental announcements; quite the contrary, we have active green investors that reward LCO... Employees, on the other hand... you would be surprised, they don't care" (Interviewee Z)

Interdependence between stakeholders and firms, as well as strong pre-existing links based on mutual affinities, trust and co-creation of value increase the potential for cooperation. In this context firms tend to favor an "overcome" strategy to deal with the barriers created by suppliers.

"Our suppliers can find other clients, but they do not want to; we have a problem because our low carbon policies are challenging for them, but we know from experience that if we support them we can count on them to make an effort" (Interviewee V)

When firms are asymmetrically dependent on their stakeholders, stakeholders' potential for cooperation is low; in this case firms will "accept" the barrier. This occurs with barriers created by government and certain clients. 
"Some stakeholders are like rocks in the way of a river; the river has to change its course around them, with the government and big clients things are like that"

(Interviewee $\mathrm{X})$

Finally, where the potential to create barriers is low, and the potential for cooperation is high, as in the case of shareholders, firms tend to favor the "explore" strategy.

"We have closely aligned our LCO targets with our strategic objectives; you could say that by doing that we are sharing risks with our shareholders; I think they expect we will share benefits" (Interviewee F).

This study notes that cooperation with stakeholders is the most widely used response mechanism for dealing with barriers, while organizational capabilities are most often used to deal with drivers. Therefore, it is necessary that organizations develop their capabilities to take advantage of opportunities and to deal with the challenges presented by their stakeholders. Moreover, this study reveals that companies with different resources and capabilities adopt different response mechanisms to barriers and drivers, which suggests that resources and capabilities influence the way a company handles these difficulties and opportunities. One example of this is "client/market attitude": while companies $\mathrm{C}$ and $\mathrm{D}$ accept this barrier, and are not actively encouraging clients to acquire low-carbon products, companies $\mathrm{F}$ and $\mathrm{U}$ explain how to moderate, reduce and, eventually, overcome that barrier:

"With the clients we have a program where we try, besides giving technical assistance and after-sales, also to give technical assistance regarding sustainability. [...] We always try to take the concepts of life cycle analysis to assist the client in their decisions." (Interviewee F).

"We have this area of sustainability and life cycle assessment [...] to produce studies to open the discussion with clients" (Interviewee U).

\section{Discussion}




\subsection{Framing relationships}

Our findings reveal the need to coordinate stakeholders, resources, and capabilities to meet the challenges and opportunities arising from climate change. The results highlight the interdependent relationships between stakeholders, organizational response mechanisms to barriers and drivers, resources and capabilities and LCO adoption. Companies seeking to understand these relationships and the adoption of LCO practices should see them as part of their environmental strategy. As proposed by Hart and Dowell (2011), organizations adopt these strategies to pursue competitive advantage in the context of climate change. In order to appropriately develop and implement these strategies, understanding the role and behavior of stakeholders as sources of barriers and drivers becomes crucial for success, as stated in recent stakeholder theory research (Barnett, Henriques and Husted, 2018; Bosse and Coughlan, 2016).

We find that the mechanisms of response (accept, overcome, explore) are influenced by the extent to which stakeholders are assessed as: a) potential barriers; and b) potential collaborators in LCO implementation. Based on stakeholder relationships research (Savage et al., 1991), we propose that this assessment of stakeholders guides companies to pursue an 'explore' mechanism of response when stakeholders are willing to collaborate and present fewer barriers. 'Accept' and 'overcome' mechanisms of response are chosen when stakeholders pose barriers.

Linnenluecke and Griffiths (2010) found that resources and capabilities influence the way a company handles barriers and opportunities for LCO adoption. Our results align with this finding, suggesting that the use of capabilities (e.g. social and environmental responsibility) increases the potential for cooperation, and moves towards the more transformational mechanisms of response 'overcome' and 'explore' (e.g. reducing employee resistance). In addition to this, in accordance with recent literature in issuestakeholders-firm interdependencies (Yakovleva and Vazquez-Brust, 2018), we note the dynamic nature of stakeholder assessment and organizational response. Firms' assessment of the nature of these relations influences the way in which they engage with stakeholders. Investing in capabilities, such participation in technical groups to communicate with the government or investment in studies on life-cycle assessment of products, as per Interviewees $\mathrm{F}$ and $\mathrm{Y}$, decreases the relational asymmetries linked to stakeholder barriers (e.g. from government and clients) to LCO implementation. This 
enables firms to progress towards transformational response mechanisms, moving from 'accept' to 'overcome'.

In agreement with Tatoglu et al., (2019), who observed that internal pressure from stakeholders, more specifically senior managers, is critical in explaining the adoption of voluntary environmental practices in developing countries, we find that shareholders have a critical role in dealing with the barriers to LCO practices. Shareholders influence sustainability goals for organizations (by means of social and environmental responsibility capability), which in turn influences the way organizations work with suppliers in order to achieve the organization's sustainability. Shareholders can support programs of participation for sharing profits and bonuses, in order to stimulate employees to develop the capabilities to pursue sustainability goals, while also reducing their resistance to environmental issues. Therefore, shareholders can reduce employees' and suppliers' potential to create barriers, while increasing their willingness to cooperate.

These findings further our understanding of the role of capabilities and the importance of stakeholder relationships in selecting mechanisms of response aimed at leveraging stakeholder engagement and creating value for the company through LCO practices.

In summary, a framework is proposed to illustrate the integrated approach between stakeholder assessment and the development/use of organizational capabilities to select an appropriate mechanism of response to deal with barriers and drivers for the adoption of LCO practices:

1) To identify the causes of drivers and barriers to the adoption of LCO practices;

2) To understand the role of stakeholders as sources of barriers and sources of cooperation for the adoption of LCO practices;

3) To analyze which mechanism of response - 'overcome', 'moderate' or 'explore' - is best suited to tackle the barriers and drivers identified;

4) To use resources and capabilities to strengthen organizational drivers in pursuing LCO practices, or to develop resources and capabilities to strengthen cooperation with stakeholders, either to deal with barriers to LCO implementation or to minimize the threat posed by stakeholders;

5) To adopt LCO practices which in turn increase the resources and organizational capabilities needed to respond to the challenges and opportunities presented by climate change. 
Figure 3 summarizes our findings and recommendations.

-Please, Insert Figure 3 here

\section{Conclusion}

This study extends the current state of knowledge on the theme of climate change and organizational strategy, by means of investigating how organizations deal with drivers and barriers to the adoption of LCO practices. It proposes a framework to guide organizations in orchestrating stakeholders, resources and capabilities to meet the challenges and opportunities presented by climate change management.

We propose that organizations can take advantage of the willingness of stakeholders to collaborate on climate change issues, by deploying capabilities and choosing suitable mechanisms of response: 'accept', 'overcome' and 'explore'.

\subsection{Academic contribution}

This article contributes to the literature on climate change and business strategy by means of testing Savage et al.'s stakeholder approach (1991) in the context of climate change. Furthermore, it combines Savage et al.'s stakeholder typology (1991) with a new analytical approach proposed by this article, called 'mechanisms of responses' to create a managerial framework to guide organizations in orchestrating stakeholders, resources and capabilities to meet the challenges and opportunities which climate change presents. Therefore, this article seeds ideas for a new perspective on how to manage stakeholders in climate change strategies. This research is at the frontier of building a new construct, according to Colquitt and Zapata-Phelan's guidelines for theoretical contributions (2007).

This article also contributes by building on Linnenluecke and Griffiths's work (2010), showing that organizations deal with drivers and barriers to climate change issues differently depending on their resources and capabilities. Tatoglu et al.'s work is also advanced (2019), and we argue that shareholders play a critical role in dealing with the barriers towards LCO practices. They are able to orchestrate capabilities in order to convert stakeholder barriers into collaboration with LCO practices.

Finally, this article addresses Herbohn et al.'s calls for a broader understanding of how companies can strategically manage their relations with stakeholders $(2014,2012)$ in order to turn a potential stakeholder barrier into an opportunity for collaboration in the implementation of LCO practices. 


\subsection{Practical contribution and managerial implications}

This article outlines the mechanisms of response needed to deal with drivers and barriers to the adoption of LCO practices, taking into account the willingness of stakeholders to collaborate with companies when tackling climate change issues. Figure 3 provides a model to help managers identify ways to explore the potential of stakeholder collaboration, utilizing organizational capabilities, in order to overcome barriers to the adoption of LCO practices. It also outlines ways to reduce the barriers posed by stakeholders in order to allow for the implementation of LCO practices. The development of capabilities plays an important role in the process of converting stakeholder barriers into potential collaboration. By and large, Figure 3 is a road map which can be used to guide managers' assessment in selecting suitable response mechanisms to deal with barriers, take advantage of drivers and identify capabilities to be deployed or developed in order to put in place a business strategy aligned with climate change adaptation.

Shareholders play a critical role in orchestrating capabilities in order to encourage unwilling stakeholders to collaborate with LCO practices. Thus, organizational capabilities for social and environmental responsibility should be nurtured by shareholders, to create a conducive environment which can overcome internal barriers to climate change actions.

This study highlights the role of government in presenting barriers, implying that governments and other organizations focused on climate change mitigation should be open to dialogue and stakeholder engagement, in order to support firms to deliver on the world's new low-carbon goals (CDP, 2016). This kind of governmental outlook could assist companies in the process of adaptation to climate change (Biesbroek et al., 2013) and in setting out optimal strategic actions (Biesbroek et al., 2013; Eisenack et al., 2014). In this sense, the Brazilian NPACC may act as an instrument to help firms engage with policymakers and succeed in dealing with climate change risks, by means of reducing potential governmental barriers.

\subsection{Limitations and directions for future research}

Inevitably, this study possesses certain limitations. For example, barriers and drivers, in many cases, were not singled out by interviewees in relation to a specific type of LCO practice; rather, they were discussed generally. Additionally, the results were 
interpreted inductively, and the information obtained from interviews was related to the relevant literature.

We do not explore the extent to which barriers, drivers and responses are contextand industry-specific; future research may use the response mechanisms proposed in this research to understand how firms in different contexts deal with barriers and drivers for the adoption of LCO practices, as well as conducting research to generalize the guidelines of the proposed framework. In this sense, empirical research should be a focus of future studies.

\section{References}

Aben, K., Hartley, I. D., \& Wilkening, K. (2010). Reducing greenhouse gas emissions in the British Columbia forest industry, 1990-2005. Technology in Society, 32(4), 288-294.

Accenture Strategy \& United Nations Global Compact. (2019). CEO study on sustainability 2019. Available on: https://www.accenture.com/_acnmedia/pdf-109/accenture-ungc-ceostudy.pdf\#zoom=50 Accessed in October, 2019.

Amit, R., \& Schoemaker, P. J. H. (1993). Strategic assets and organizational rent. Strategic Management Journal, 14(1)33-46.

Baranova, P., \& Meadows, M. (2017). Engaging with environmental stakeholders: Routes to building environmental capabilities in the context of the low-carbon economy. Business Ethics: A European Review, 26(2), 112-129.

Barnett, M. L., Henriques, I., \& Husted, B. (2018). The rise and stall of stakeholder influence: How the digital age limits social control. Academy of Management Perspectives. Advance online publication. doi: 10.5465/amp.2017.0080

Barney, J. B. (1991). Firm resources and sustained competitive advantage. Journal of management, 17(1), 99-120.

Barney, J. B., Ketchen Jr., D. J., \& Wright, M. (2011). The Future of Resource-Based Theory: Revitalization or Decline?. Journal of Management, 37(5), 1299-1315.

Biesbroek, G. R., Klostermann, J. E., Termeer, C. J., \& Kabat, P. (2013). On the nature of barriers to climate change adaptation. Regional Environmental Change, 13(5), 1119-1129.

Boiral, O., Henri, J. F., \& Talbot, D. (2012). Modeling the Impacts of Corporate Commitment on Climate Change. Business Strategy and the Environment, 21(8), 495-516.

Bosse, D. A., \& Coughlan, R. (2016). Stakeholder relationship bonds. Journal of Management Studies, 53, 1197-1222.

Böttcher, C. F., \& Müller, M. (2015). Drivers, practices and outcomes of low-carbon operations: approaches of german automotive suppliers to cutting carbon emissions. Business Strategy and the Environment, 24(6), 477-498.

Burch, S. (2010). In pursuit of resilient, low carbon communities: An examination of barriers to action in three Canadian cities. Energy Policy, 38(12), 7575-7585.

Cadez, S., Czerny, A., \& Letmathe, P. (2019). Stakeholder pressures and corporate climate change mitigation strategies. Business Strategy and the Environment, 28(1), 1-14.

Carlsson-Kanyama, A., Carlsen, H., \& Dreborg, K-H. (2013). Barriers in Municipal Climate Change Adaptation: Results from Case Studies using Backcasting. Futures, 49, 9-21. 
CDP (Carbon Disclosure Program). (2016). Out of the starting blocks: Tracking progress on corporate climate action. Available on https://s3.amazonaws.com/assets.wemeanbusinesscoalition.org/wpcontent/uploads/2016/11/03183855/CDP_Climate_Change_Report_2016_Web_Pages_0. pdf Accessed February/2019

CDP (Carbon Disclouse Program). (2014). Conexão entre mudanças climáticas e modelos de negócios: uma agenda em evolução. Available on: https://edisciplinas.usp.br/pluginfile.php/1066016/mod_resource/content/0/CDP_Brazil_1 00_Climate_Change_Report_pt.pdf

Chan, W. (2012). Energy benchmarking in support of low carbon hotels: Developments, challenges, and approaches in China. International Journal of Hospitality Management, 31(4), 1130-1142.

Chen, X., Luo, Z., \& Wang, X. (2017). Impact of efficiency, investment, and competition on low carbon manufacturing. Journal of Cleaner Production, 143, 388-400.

Childe, S. J. (2007). Can operations managers save the world?. Production Planning \& Control, 18(2), 73.

Choi, D., \& Hwang, T. (2015). The impact of green supply chain management practices on firm performance: the role of collaborative capability. Operations Management Research, 8(34), 69-83.

Chomaitong, S., \& Perera, R. (2014). Adoption of the low carbon society policy in locallygoverned urban areas: experience from Thai municipalities. Mitigation and Adaptation Strategies for Global Change, 19(8), 1255-1275.

Chu, S. Y., \& Schroeder, H. (2010). Private Governance of Climate Change in Hong Kong: An Analysis of Drivers and Barriers to Corporate Action. Asian Studies Review, 34(3), 287308.

Clarke, V., \& Braun, V. (2006). Using thematic analysis in psychology. Qualitative Research in Psychology, 3(2), 77-101.

Colquitt, J. A., \& Zapata-Phelan, C. P. (2007). Trends in theory building and theory testing: A five-decade study of the Academy of Management Journal, 50(6), 1281-1303.

Dasaklis, T. K., \& Pappis, C. P. (2013). Supply chain management in view of climate change: An overview of possible impacts and the road ahead. Journal of Industrial Engineering and Management. 6(4), 1139-1161.

Dilling, L., \& Failey, E. (2013). Managing carbon in a multiple use world: The implications of land-use decision context for carbon management. Global Environmental Change, 23(1), 291-300.

Dulal, H. B., Brodnig, G., \& Shah, K. U. (2011). Capital assets and institutional constraints to implementation of greenhouse gas mitigation options in agriculture. Mitigation and Adaptation Strategies for Global Change, 16(1), 1-23.

Eesley, C., \& Lenox, M. J. (2006). Firm responses to secondary stakeholder action. Strategic Management Journal, 27, 765-781

Eisenack, K., Moser, S. C., Hoffmann, E., Klein, R. J. T., Oberlack, C., Pechan, A., Rotter, M., \& Termeer, C. J. A. M. (2014). Explaining and overcoming barriers to climate change adaptation. Nature Climate Change, 4(10), 867-872.

Erzurumlu, S. S., \& Erzurumlu, Y. O. (2013). Development and deployment drivers of clean technology innovations. Journal of High Technology Management Research, 24, 100-108. 
Fleiter, T., Gruber, E., Eichhammer, W., \& Worrell, E. (2012). The German energy audit program for firms-a cost-effective way to improve energy efficiency?. Energy Efficiency, 5(4), 447469.

Ford, J. D., Pearce, T., Prno, J., Duerden, F., Ford, L. B., Beaumier, M., \& Smith, T. (2010). Perceptions of climate change risks in primary resource use industries: A survey of the Canadian mining sector. Regional Environmental Change, 10(1), 65-81.

Freeman, E. R., \& Mc Vea, J. (2001). Stakeholder Approach to Strategic Management. In Hitt, M. A., Freeman, E. R., \& Harrison, J. S. (eds.), Handbook of Strategic Management $1^{\text {st }}$ edition, (pp. 189-207). Blackwell Publishing, Oxford.

Galbreath, J. (2014). Climate change response: Evidence from the Margaret River wine region of Australia. Business Strategy and the Environment, 23(2), 89-104.

Garbuzova, M., \& Madlener, R. (2012). Towards an Efficient and Low Carbon Economy Post2012: Opportunities and Barriers for Foreign Companies in the Russian Energy Market. Mitigation and Adaptation Strategies for Global Change, 17(4), 387-413.

Gasbarro, F., \& Pinkse, J. (2016). Corporate Adaptation Behaviour to Deal with Climate Change: The Influence of Firm-Specific Interpretations of Physical Climate Impacts. Corporate Social Responsibility and Environmental Management, 23(3), 179-192.

Giesekam, J., Barrett, J., Taylor, P., \& Owen, A. (2014). The greenhouse gas emissions and mitigation options for materials used in UK construction. Energy and Buildings, 78, 202214.

Glienke, N., \& Guenther, E. (2016). Corporate climate change mitigation: a systematic review of the existing empirical evidence. Management Research Review, 39(1), 2-34.

Goworek, H., Land, C., Burt, G., Zundel, M., Saren, M., Parker, M., \& Lambe, B. (2018). Scaling sustainability: Regulation and resilience in managerial responses to climate change. British Journal of Management, 29(2), 209-219.

Guoyou, Q., Saixing, Z., Chiming, T., Haitao, Y., \& Hailiang, Z. (2013). Stakeholders' Influences on Corporate Green Innovation Strategy: A Case Study of Manufacturing Firms in China. Corporate Social Responsibility and Environmental Management, 20, 1-14.

Hart, S. L. (1995). A Natural-Resource-Based View of the firm. Academy of Management Review, 20(4), 986-1014.

Hart, S. L., \& Dowell, G. (2011). A Natural-Resource-Based View of the Firm: Fifteen Years After. Journal of Management, 37(5), 1464-1479.

He, Z., Chen, P., Liu, H., \& Guo, Z. (2017). Performance measurement system and strategies for developing low-carbon logistics: A case study in China. Journal of Cleaner Production, 156, 395-405.

Heidenreich, M. (2009). Innovation patterns and location of European low-and mediumtechnology industries. Research Policy, 38(3), 483-494.

Heikkinen, A. (2017). Business Climate Change Engagement: Stakeholder Collaboration in Multi-stakeholder Networks. In Stakeholder Engagement: Clinical Research Cases (pp. 231-253). Springer, Cham.

Herbohn, K., Dargusch, P., \& Herbohn, J. (2012). Climate Change Policy in Australia: Organizational Responses and Influences. Australian Accounting Review, 22(2), 208-222.

Herbohn, K., Walker, J., \& Loo, H. Y. M. (2014). Corporate Social Responsibility: The Link Between Sustainability Disclosure and Sustainability Performance. Abacus, 50(4), 422459. 
Herrmann, J., \& Guenther, E. (2017). Exploring a scale of organizational barriers for enterprises' climate change adaptation strategies. Journal of Cleaner Production, 160, 38-49.

Hoskisson, R. E., Hitt, M. A., Wan, W. P., \& Yiu, D. (1999). Theory and research in strategic management: Swings of a pendulum. Journal of Management, 25(3), 417-456.

IPCC (Intergovernmental Panel on Climate Change). (2014). Impacts, Adaptation, and Vulnerability Part A: Global and Sectorial Aspects. Retrieved from https://www.ipcc.ch/pdf/assessment-report/ar5/wg2/drafts/fd/WGIIAR5Chap16_FGDall.pdf. Accessed 28 Feb 2016.

Jaber, J. O., \& Probert, S. D. (2001). $\mathrm{CO}_{2}$ mitigation options and barriers to implementation in the Jordanian energy-sector. Applied Energy, 70(1), 1-15.

Jeswani, H. K., Wehrmeyer, W., \& Mulugetta, Y. (2008). How warm is the corporate response to climate change? Evidence from Pakistan and the UK. Business Strategy and the Environment, 17(1), 46-60.

Joia, L. A., Soler, A. M., Bernat, G. B., \& Rabechini Jr, R. (2013). Gerenciamento de riscos em projetos. Editora FGV: Rio de Janeiro, RJ.

Jones, A. W. (2015). Perceived barriers and policy solutions in clean energy infrastructure investment. Journal of Cleaner Production, 104, 297-304.

Jongh, D., \& Möllmann, C. M. (2014). Market barriers for voluntary climate change mitigation in the South African private sector. South African Journal of Economic and Management Sciences, 17(5), 639-652.

Kavouridis, K., \& Koukouzas, N. (2008). Coal and sustainable energy supply challenges and barriers. Energy Policy, 36(2), 693-703.

Kolk, A., \& Pinkse, J. (2008). A perspective on multinational enterprises and climate change: Learning from "an inconvenient truth"?. Journal of International Business Studies, 39(8), 1359-1378.

Lah, O. (2015). The barriers to low-carbon land-transport and policies to overcome them. European Transport Research Review, 7(5), 3-11.

Lee, K-H. (2015). Drivers and Barriers to Energy Efficiency Management for Sustainable Development. Sustainable Development, 23(1), 16-25.

Lee, S-Y. (2012). Corporate carbon strategies in responding to climate change. Business Strategy and the Environment, 21(1), 33-48.

Lee, Z. H., Sethupathi, S., Lee, K. T., Bhatia, S., \& Mohamed, A. R. (2013). An overview on global warming in Southeast Asia: $\mathrm{CO}_{2}$ emission status, efforts done, and barriers. Renewable and Sustainable Energy Reviews, 28, 71-81.

Lemieux, C. J., Thompson, J. L., Dawson, J., \& Schuster, R. M. (2013). Natural resource manager perceptions of agency performance on climate change. Journal of Environmental Management, 114, 178-189.

Li, J., Liang, X., Cockerill, T., Gibbins, J., \& Reiner, D. (2012). Opportunities and barriers for implementing $\mathrm{CO}_{2}$ capture ready designs: A case study of stakeholder perceptions in Guangdong, China. Energy Policy, 45, 243-251.

Linnenluecke, M., \& Griffiths, A. (2010). Beyond Adaptation: Resilience for Business in Light of Climate Change and Weather Extremes. Business \& Society, 49(3), 477-511.

Liu, L. Q., Liu, C. X., \& Sun, Z. Y. (2011). A survey of China's low-carbon application practice - Opportunity goes with challenge. Renewable and Sustainable Energy Reviews, 15(6), 2895-2903. 
Liu, Y. (2012). An empirical research of awareness, behavior and barriers to enact carbon management of industrial firms in China. Science of the Total Environment, 425, 1-8.

Liu, Y. (2014). Barriers to the adoption of low carbon production: A multiple-case study of Chinese industrial firms. Energy Policy, 67, 412-421.

Lo, S. F. (2010). Global warming action of Taiwan's semiconductor/TFT-LCD industries: How does voluntary agreement work in the IT industry?. Technology in Society, 32(3), 249-254.

Marcondes, D., \& Canto, R. (2015). O sopro de esperança da COP21. Carta Capital. Available in: http://www.cartacapital.com.br/revista/881/sopro-de-esperanca. Accessed 05 Oct 2016.

Martinsen, U., \& Huge-Brodin, M. (2014). Environmental practices as offerings and requirements on the logistics market. Logistics Research, 7(1), 115-137.

MMA (Ministério do Meio Ambiente do Brasil). (2019). Plano Nacional de Adaptação à Mudança Climática: Estratégias Setoriais e Climáticas. Available on: http://www.mma.gov.br/clima/adaptacao/plano-nacional-de-adaptacao

Ng, S. T., Skitmore, M., \& Cheung, J. N. H. (2013). Organizational obstacles to reducing carbon emissions in Hong Kong. Habitat International, 40, 119-126.

Okereke, C. (2007). An Exploration of Motivations, Drivers and Barriers to Carbon Management: The UK FTSE 100. European Management Journal, 25(6), 475-486.

Okereke, C., \& Kung, K. (2013). Climate policy and business climate strategies: EU cement companies' response to climate change and barriers against action. Management of Environmental Quality: An International Journal, 24(3), 286-310.

Okereke, C., Wittneben, B., \& Bowen, F. (2012). Climate Change: Challenging Business, Transforming Politics. Business and Society, 51(1), 7-30.

Pålsson, H., \& Kovács, G. (2014). Reducing transportation emissions: a reaction to stakeholder pressure or a strategy to increase competitive advantage. International Journal of Physical Distribution \& Logistics Management, 44(4), 283-304.

Pasquini, L., Cowling, R. M., \& Ziervogel, G. (2013). Facing the heat: Barriers to mainstreaming climate change adaptation in local government in the Western Cape Province, South Africa. Habitat International, 40, 225-232.

Pegels, A. (2010). Renewable energy in South Africa: Potentials, barriers and options for support. Energy Policy, 38(9), 4945-4954.

Pesonen, H. L., \& Horn, S. (2014). Evaluating the climate SWOT as a tool for defining climate strategies for business. Journal of Cleaner Production, 64, 562-571.

Pinkse, J., \& Busch, T. (2013). The emergence of corporate carbon norms: Strategic directions and managerial implications. Thunderbird International Business Review, 55(6), 633-645.

Pinner, D, . \& Sneader, K. (2019). Earth to CEO: your company is already at risk from climate change. Available on: https://www.mckinsey.com/business-functions/sustainability/ourinsights/earth-to-ceo-your-company-is-already-at-risk-from-climate-change Accessed in October, 2019.

Pitt, D., \& Randolph, J. (2009). Identifying obstacles to community climate protection planning. Environment and Planning C: Government and Policy, 27(5), 841-857.

PWC (PricewaterhouseCoopers). (2016). The Paris Agreement: A turning point? The Low Carbon Economy Index 2016. Retrieved from https://www.pwc.com/ee/et/publications/pub/low-carbon-economy-index-2016.pdf. Accessed 5 Oct 2017.

Rasi, R. Z. R. M., Abdekhodaee, A., \& Nagarajah, R. (2014). Stakeholders' involvements in the implementation of proactive environmental practices: Linking environmental practices and 
environmental performances in SMEs. Management of Environmental Quality: An International Journal, 25(2), 132-149.

Reyers, M., Gouws, D., \& Blignaut, J. (2011). An exploratory study of motivations driving corporate investment in voluntary climate change mitigation in South Africa. South African Journal of Economic and Management Sciences, 14(1), 92-108.

Roarty, M. (1997). Greening business in a market economy. European Business Review, 97(5), 244-254.

Rojšek, I. (2001). From red to green: Towards the environmental management in the country in transition. Journal of Business Ethics, 33(1), 37-50.

Rowley, J. (2012). Conducting research interviews. Management Research Review, 35(3/4) 260271.

Sakhel, A. (2017). Corporate climate risk management: Are European companies prepared?. Journal of Cleaner Production, 165, 103-118.

Savage, G. T., Nix, T. W., Whitehead, C. J., \& Blair, J. D. (1991). Strategies for assessing and managing organizational stakeholders. Academy of management perspectives, 5(2), 61-75.

Sentance, A. (2009). Developing transport infrastructure for the Low Carbon Society. Oxford Review of Economic Policy, 25(3), 391-410.

Shaw, D., Cumbers, A., McMaster, R., \& Crossan, J. (2018). Scaling up community action for tackling climate change. British Journal of Management, 29(2), 266-278.

Smith, W. K. (2014). Dynamic decision making: A model of senior leaders managing strategic paradoxes. Academy of Management Journal, 57(6), 1592-1623.

Sprengel, D. C., \& Busch, T. (2011). Stakeholder engagement and environmental strategy-the case of climate change. Business Strategy and the Environment, 20(6), 351-364.

Sullivan, R. (2009). The management of greenhouse gas emissions in large European companies. Corporate Social Responsibility and Environmental Management, 16(6), 301-309.

Tait, E., Laing, R., \& Gray, D. (2014). Governance and policy challenges of implementing urban low-carbon transport initiatives. Local Economy, 29(1-2), 129-140.

Tantalo, C., \& Priem, R. L. (2016). Value creation through stakeholder synergy. Strategic Management Journal, 37, 314-329.

Tatoglu, E., Frynas, J. G., Bayraktar, E., Demirbag, M., Sahadev, S., Doh, J., \& Koh, S. L. (2019). Why do Emerging Market Firms Engage in Voluntary Environmental Management Practices? A Strategic Choice Perspective. British Journal of Management, in press.

The Economist. Why is climate change so hard to tackle? Available on: https://www.economist.com/leaders/2018/12/01/why-is-climate-change-so-hard-to-tackle Accessed in October, 2019.

Ürge-Vorsatz, D., Novikova, A., Koppel, S., \& Boza-Kiss, B. (2009). Bottom-up assessment of potentials and costs of $\mathrm{CO}_{2}$ emission mitigation in the buildings sector: Insights into the missing elements. Energy Efficiency, 2(4), 293-316.

Wang, D. D. (2017). Do United States manufacturing companies benefit from climate change mitigation technologies?. Journal of Cleaner Production, 161, 821-830.

Weinhofer, G., \& Hoffmann, V. H. (2010). Mitigating climate change-how do corporate strategies differ?. Business Strategy and the Environment, 19(2), 77-89.

Winston, A. What 1,000 CEOs really think about climate change and inequality. Harvard Business Review. Available on: https://hbr.org/2019/09/what-1000-ceos-really-thinkabout-climate-change-and-inequality Accessed in October, 2019. 
Wong, P. S. P., Ng, S. T. T., \& Shahidi, M. (2013). Towards understanding the contractor's response to carbon reduction policies in the construction projects. International Journal of Project Management, 31(7), 1042-1056.

Wood, D. J., Mitchell, R. K., Agle, B. R., \& Bryan, L. M. (2018). Stakeholder Identification and Salience After 20 Years: Progress, Problems, and Prospects. Business \& Society, 0007650318816522 .

Yakovleva, N., \& Vazquez-Brust, D. A. (2018). Multinational mining enterprises and artisanal small-scale miners: From confrontation to cooperation. Journal of World Business, 53(1), $52-62$.

Zhang, B., \& Wang, Z. (2014). Inter-firm collaborations on carbon emission reduction within industrial chains in China: Practices, drivers and effects on firms' performances. Energy Economics, 42, 115-131.

Zhu, Q., \& Geng, Y. (2013). Drivers and barriers of extended supply chain practices for energy saving and emission reduction among Chinese manufacturers. Journal of Cleaner Production, 40, 6-12.

Zilahy, G. (2004). Organisational factors determining the implementation of cleaner production measures in the corporate sector. Journal of cleaner production, 12(4), 311-319 
STAKEHOLDER'S POTENCIAL FOR THREAT

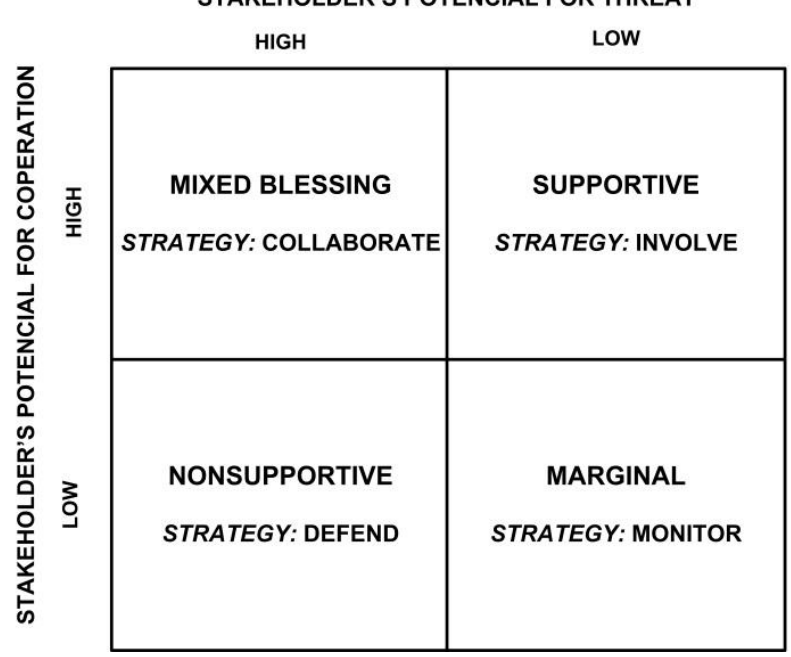

Figure 1 - Typology of stakeholders of organizations and strategies for dealing with them. Source: adapted from Savage et al. (1991). 
Table 1 - Barriers and drivers caused by stakeholders.

Source: Authors

\begin{tabular}{|c|c|c|c|c|c|c|c|c|c|c|c|c|c|c|c|c|c|c|c|c|c|c|c|c|c|c|c|c|c|c|c|c|c|c|c|c|c|c|c|c|c|}
\hline Barriers/Drivers & 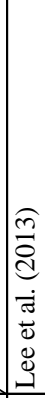 & 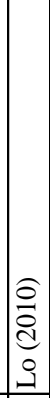 & 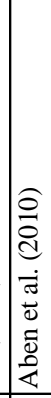 & 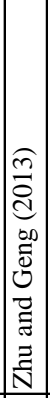 & 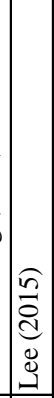 & 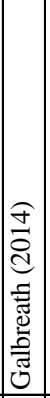 & 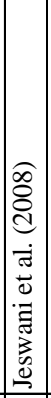 & 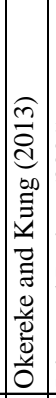 & 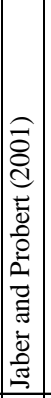 & 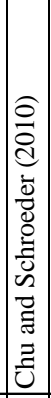 & 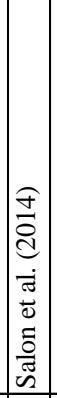 & 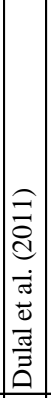 & 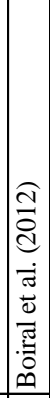 & 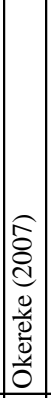 & 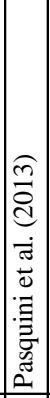 & 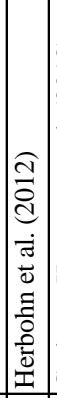 & 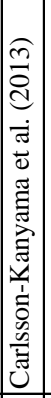 & 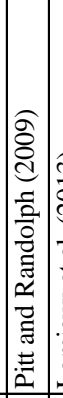 & 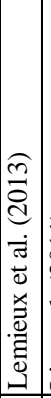 & (2) & 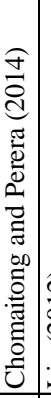 & 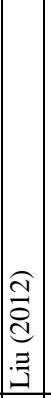 & 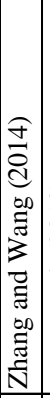 & 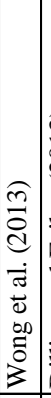 & 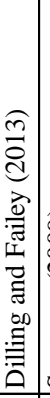 & 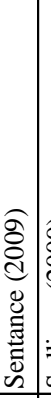 & 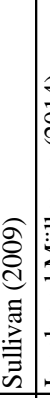 & & 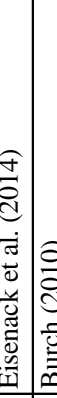 & 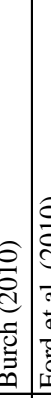 & 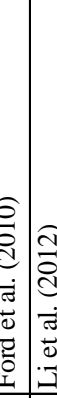 & 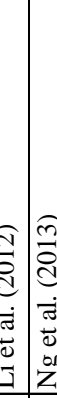 & & 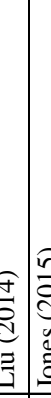 & 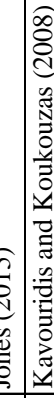 & 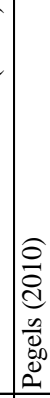 & 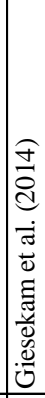 & 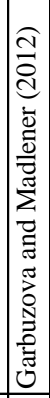 & 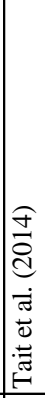 & & $\stackrel{5}{0}$ \\
\hline Divergence/Incompatibility policies & $\mathrm{X}$ & & & & & & $\mathrm{X}$ & $\mathrm{X}$ & $\mathrm{X}$ & & & & & & $\mathrm{X}$ & & & & & & & & & & $\mathrm{X}$ & & & & & $\mathrm{X}$ & & & & & & & & $\mathrm{X}$ & & & 8 \\
\hline Deficiency policies & $\mathrm{X}$ & & & & & & & & & $\mathrm{X}$ & & $\mathrm{X}$ & & $\mathrm{X}$ & $\mathrm{X}$ & $\mathrm{X}$ & & $\mathrm{X}$ & & & & & & & & & & & & & & & & & & & & $\mathrm{X}$ & & & 8 \\
\hline Customer/Market attitude & & $\mathrm{X}$ & $\mathrm{X}$ & $\mathrm{X}$ & & $\mathrm{X}$ & & & & $\mathrm{X}$ & & & $\mathrm{X}$ & $\mathrm{X}$ & & $\mathrm{X}$ & & & & & $\mathrm{X}$ & $\mathrm{X}$ & & & & & & & & & & $\mathrm{X}$ & $\mathrm{X} \mid \mathrm{y}$ & $\mathrm{X}$ & $\mathrm{X}$ & & $\mathrm{X}$ & & $\mathrm{X}$ & $\mathrm{X}$ & 16 \\
\hline Pressure from International Institutions & & $\mathrm{X}$ & & & & & & & & & & & & & & & & & & & & & & & & & & & & & & & & & & & & & & & 1 \\
\hline Voluntary Emission Reduction Programs & & & $\mathrm{X}$ & & & & & & & & & & & & & & & & & & & & & & & & & & & & & & & & & & & & & & 1 \\
\hline Government Legislation and established policies & & & $\mathrm{X}$ & & & & $\mathrm{X}$ & $\mathrm{X}$ & $\mathrm{X}$ & $\mathrm{X}$ & $\mathrm{X}$ & & $\mathrm{X}$ & $\mathrm{X}$ & $\mathrm{X}$ & & & & $\mathrm{X}$ & $\mathrm{X}$ & $\mathrm{X}$ & $\mathrm{X}$ & & & $\mathrm{X}$ & 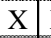 & 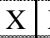 & 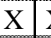 & $\mathrm{X} \mid \mathrm{X}$ & 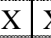 & $\mathrm{x} \mid \mathrm{x}$ & $\mathrm{X}$ & & $\mathrm{X} \mid \mathrm{X}$ & & & $\mathrm{X}$ & & & & 25 \\
\hline Media Pressure & & & & $\mathrm{X}$ & & & & & & & & & & & & & & & & & & & & & & & & & & & & & & & & & & & & & 1 \\
\hline Support/Incentives/Taxes/Government charges & & & & & $\mathrm{X}$ & & & $\mathrm{X}$ & $\mathrm{X}$ & $\mathrm{X}$ & & $\mathrm{X}$ & & & $\mathrm{X}$ & & $\mathrm{X}$ & $\mathrm{X}$ & & & $\mathrm{X}$ & & & $\mathrm{X}$ & & $\mathrm{X}$ & & & & $\mathrm{X}$ & $\mathrm{x}$ & $\mathrm{x} \mid \mathrm{X}$ & & & & & & & & & 14 \\
\hline Owners/Shareholders demand & & & & & $\mathrm{X}$ & & & & & & & & $\mathrm{X}$ & $\mathrm{X}$ & & & & & & & & & & & & & & & & & & $x$ & & & & & & & & & 4 \\
\hline Supply chain requirements & & & & & & & & & & $\mathrm{X}$ & & & & & & $\mathrm{X}$ & & & & & & & $\mathrm{X}$ & & & & & & & & & & & & & & & & & & 3 \\
\hline Society's Attitude & & & & & & & & & & & & $\mathrm{X}$ & & & & & & $\mathrm{X}$ & & & $\mathrm{X}$ & & & & & & & & & & & & & & & & & & & & 3 \\
\hline Matrix Requirements & & & & & & & & & & & & & $\mathrm{X}$ & & & & & & & & & & & & & & & & & & & & & & & & & & & & 1 \\
\hline Uncertainty about Government Action & & & & & & & & & & & & & & $\mathrm{X}$ & & & & & & & & $\mathrm{X}$ & & & & & & & & & & & & $\mathrm{X}$ & & & $\mathrm{X}$ & & & & 4 \\
\hline Continuous change in the economic and political context & & & & & & & & & & & & & & & & & & & & & & & & & & & & & & & & & & & & & & $\mathrm{X}$ & & & 1 \\
\hline Information/Availability/Adequate technology (suppliers) & & & & & & & $\mathrm{X}$ & & $\mathrm{X}$ & & & & & & & & & & & & $\mathrm{X}$ & $\mathrm{X}$ & & & & & & & $\mathrm{X}$ & & & $x$ & & $\mathrm{X} \mid \mathrm{y}$ & $\mathrm{x}$ & $\mathrm{X}$ & $\mathrm{X}$ & $\mathrm{X}$ & & & 11 \\
\hline Sector Strict Standards & & & & & & & & & & & & & & & & & & & & & & & & $\mathrm{X}$ & & & & & & & & & & & & & & & & & 1 \\
\hline
\end{tabular}


Table 2 - Internal barriers and drivers caused by resources and capabilities.

Source: Authors

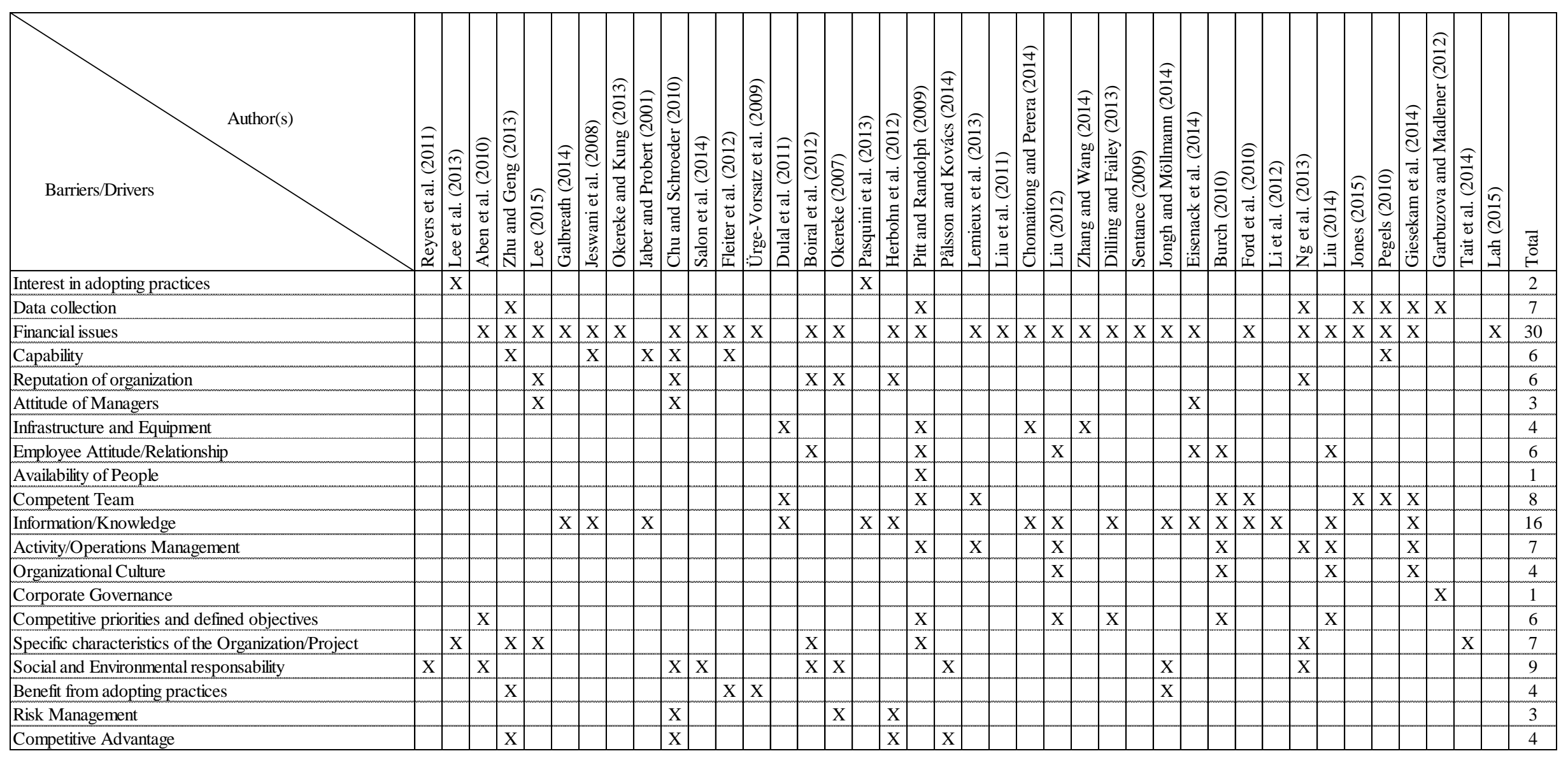




\begin{tabular}{|c|c|c|}
\hline $\begin{array}{c}\text { Mechanisms of } \\
\text { response to barriers }\end{array}$ & $\begin{array}{c}\text { Mechanisms of } \\
\text { response to drivers }\end{array}$ & Action \\
\hline Accept & Accept & Don't act/monitor \\
\hline Reduce & Improve & Focus on the probability/or on the current impact \\
\hline Overcome & Explore & Focus on the root cause \\
\hline
\end{tabular}

Chart 1 - Framework of mechanisms of responses to deal with barriers and drivers for adoption of LCO.

Source: Authors, based on Joia et al. (2013)

Table 3 - Positions of interviewees within the companies studied.

\begin{tabular}{cc}
\hline Role & Number \\
\hline Technician & 1 \\
Analyst & 6 \\
Specialist & 3 \\
Consultant & 1 \\
Engineer & 3 \\
Coordinator & 2 \\
Manager & 8 \\
\hline
\end{tabular}

Table 4 - Number of companies studied by sector, according to OECD classification.

\begin{tabular}{cc}
\hline Sector & Amount \\
\hline High Tech & 3 \\
Medium-High Tech & 5 \\
Medium-Low Tech & 4 \\
Low Tech & 3 \\
Construction \& Primary & 5 \\
Knowledge Intensive Services & 4 \\
\hline
\end{tabular}

Note: Some of the companies studied are from the following economic sectors - engineering and construction, cosmetics, fragrance and chemical. 
Table 5 - LCO practices adopted by the companies studied.

\begin{tabular}{|c|c|c|}
\hline LCO Practice & Most Adopted Actions & Interviewees' comments \\
\hline \multirow[t]{3}{*}{ Low-carbon Products } & $\begin{array}{l}\text { Substitution of raw materials } \\
\text { which have a high carbon } \\
\text { footprint }\end{array}$ & $\begin{array}{c}\text { "We reduced the size of the } \\
\text { packaging, we use cartons } \\
\text { instead of plastic, because it's } \\
\text { more renewable and recyclable" } \\
\text { (Interviewee } N)\end{array}$ \\
\hline & $\begin{array}{l}\text { Reduction in the consumption of } \\
\text { raw materials }\end{array}$ & $\begin{array}{c}\text { "We use more cement slags and } \\
\text { less lime content" (Interviewee } \\
G)\end{array}$ \\
\hline & $\begin{array}{l}\text { Use of renewable and recyclable } \\
\text { materials in product } \\
\text { manufacturing and packaging }\end{array}$ & $\begin{array}{l}\text { "The package has to be as } \\
\text { recyclable as possible" } \\
\text { (Interviewee E) }\end{array}$ \\
\hline \multirow[t]{3}{*}{ Low-carbon Production } & Use of efficient technologies & $\begin{array}{l}\text { "The company has implemented } \\
\text { software for the power } \\
\text { consumption of the large } \\
\text { equipment at work [...]. This } \\
\text { software plans how you will use } \\
\text { the equipment" (Interviewee G) }\end{array}$ \\
\hline & Reduction of waste & $\begin{array}{l}\text { "We can use a large portion of } \\
\text { the dishes that didn't pass quality } \\
\text { inspection, through shredding } \\
\text { and reuse in your own product } \\
\text { mass" (Interviewee I) }\end{array}$ \\
\hline & $\begin{array}{l}\text { Increasing the reuse and } \\
\text { recycling of waste }\end{array}$ & $\begin{array}{l}\text { "The company has to think of the } \\
\text { reduction of industrial waste } \\
\text { generation; so, we're not } \\
\text { thinking only in destination but } \\
\text { have to think in reducing" } \\
\text { (Interviewee J) }\end{array}$ \\
\hline \multirow[t]{3}{*}{ Low-carbon Logistics } & $\begin{array}{l}\text { Use of biofuel and electric } \\
\text { vehicles }\end{array}$ & $\begin{array}{l}\text { "We block the cards so that they } \\
\text { [vehicles] are refilled only with } \\
\text { ethanol" (Interviewee O) }\end{array}$ \\
\hline & Definition of the best routes & $\begin{array}{l}\text { "Using the vehicle to its full } \\
\text { capacity, to its destination and } \\
\text { back" (Interviewee B) }\end{array}$ \\
\hline & & $\begin{array}{l}\text { "We chose the carriers that have } \\
\text { the best routes for our deliveries } \\
\text { and collections, and always } \\
\text { travel with partially loaded } \\
\text { vehicles" (Interviewee D) }\end{array}$ \\
\hline
\end{tabular}


Table 6 - Barriers to adoption of LCO.

\begin{tabular}{|c|c|c|}
\hline Influencer (Source) & Barriers & Interviewees' comments \\
\hline Suppliers (stakeholders) & $\begin{array}{l}\text { Lack of availability and } \\
\text { adequacy of more efficient } \\
\text { technologies and their attitudes } \\
\text { and relationship with the } \\
\text { company }\end{array}$ & $\begin{array}{l}\text { "It's a little harder when you } \\
\text { work with small suppliers, who } \\
\text { don't have the handling of } \\
\text { climate change in their routines } \\
\text { yet" (Interviewee Q) } \\
\text { "Technology has to be available } \\
\text { and commercialized, and with } \\
\text { an appropriate cost" } \\
\text { (Interviewee F) }\end{array}$ \\
\hline Government (stakeholders) & $\begin{array}{l}\text { Lack of support and tax } \\
\text { incentives for adoption of LCO }\end{array}$ & $\begin{array}{c}\text { "The company studies the } \\
\text { solution, invests in having the } \\
\text { equipment, and the government } \\
\text { has to do its part by } \\
\text { encouraging the adoption of } \\
\text { these technologies" (Interviewee } \\
\mathrm{T} \text { ) }\end{array}$ \\
\hline Clients (stakeholders) & $\begin{array}{l}\text { Clients opt for cheaper options } \\
\text { without regard to environmental } \\
\text { issues }\end{array}$ & $\begin{array}{c}\text { "There are clients that } \\
\text { sometimes opt for conventional } \\
\text { products because of the price" } \\
\text { (Interviewee C) }\end{array}$ \\
\hline Financial issues (resources) & $\begin{array}{l}\text { High cost of practices which, } \\
\text { consequently, have a long payoff } \\
\text { period }\end{array}$ & $\begin{array}{l}\text { "Projects are evaluated, they } \\
\text { have several environmental } \\
\text { benefits, but when it comes to } \\
\text { the financial viability and even } \\
\text { the return, it is barred because } \\
\text { the return comes after 15, } 20 \\
\text { years" (Interviewee M) }\end{array}$ \\
\hline Employees' attitudes (resources) & $\begin{array}{l}\text { Resistance, aversion to change, } \\
\text { or lack of sensitivity to } \\
\text { environmental issues }\end{array}$ & $\begin{array}{l}\text { "Unfortunately, Brazilian } \\
\text { people do not have the } \\
\text { [environmental] culture" } \\
\text { (Interviewee T) } \\
\text { "We need to review some } \\
\text { patterns of consumption, } \\
\text { standards regarding our criteria } \\
\text { of choice, this comes since the } \\
\text { development of each one as a } \\
\text { child" (Interviewee F) }\end{array}$ \\
\hline
\end{tabular}


Table 7 - Drivers for the adoption of LCO.

\begin{tabular}{|c|c|c|}
\hline Influencer (Source) & Drivers & Interviewees' comments \\
\hline $\begin{array}{l}\text { Shareholders and owners } \\
\text { (stakeholders) }\end{array}$ & Support from top management & $\begin{array}{l}\text { "The demands of shareholders } \\
\text { and directors contribute to us } \\
\text { gaining strength to implement } \\
\text { the project" (Interviewee E) }\end{array}$ \\
\hline Clients (stakeholders) & $\begin{array}{l}\text { Clients demand that companies } \\
\text { pollute less, and invest in } \\
\text { products with a lower carbon } \\
\text { footprint }\end{array}$ & $\begin{array}{c}\text { "Clients [...] are quite engaged } \\
\text { in sustainability, so they } \\
\text { encourage us a lot" } \\
\text { (Interviewee S) }\end{array}$ \\
\hline Financial issues (resources) & $\begin{array}{l}\text { LCO practices can also result in } \\
\text { savings for organizations }\end{array}$ & $\begin{array}{l}\text { "The issue of operating costs is } \\
\text { the first one; We are improving } \\
\text { the efficiency of our processes } \\
\text { by using less fuel and how we } \\
\text { deal with dealing directly with } \\
\text { costs [...]; the issue of waste } \\
\text { projects, you are also avoiding } \\
\text { an extraction and a purchase of } \\
\text { raw materials" (Interviewee I) }\end{array}$ \\
\hline $\begin{array}{l}\text { Social and environmental } \\
\text { responsibility (capabilities) }\end{array}$ & $\begin{array}{l}\text { Compromise between an } \\
\text { organization and its } \\
\text { stakeholders }\end{array}$ & $\begin{array}{l}\text { "Maybe, we even spend a little } \\
\text { bit, because it's in not every } \\
\text { place that the ethanol makes up } \\
\text { for the gas, but even so we } \\
\text { prioritize ethanol thinking of the } \\
\text { environment" (Interviewee A) }\end{array}$ \\
\hline $\begin{array}{l}\text { Competitive advantage } \\
\text { (capabilities) }\end{array}$ & $\begin{array}{l}\text { Perception of business } \\
\text { opportunities through the } \\
\text { adoption of LCO practices }\end{array}$ & $\begin{array}{l}\text { "We reduce production costs } \\
\text { and there are more competitive } \\
\text { products on the market because } \\
\text { of the price issue" (Interviewee } \\
\text { D) } \\
\text { "These actions strengthen the } \\
\text { brand, strengthen the business } \\
\text { as a proactive, responsible } \\
\text { company, concerned with the } \\
\text { generation of value for the } \\
\text { various stakeholders" } \\
\text { (Interviewee I) }\end{array}$ \\
\hline
\end{tabular}

Table 8 - Mechanisms of responses to barriers to LCO practices adoption. 


\begin{tabular}{|c|c|c|}
\hline Source of Barrier & $\begin{array}{l}\text { Mechanisms of Response } \\
\text { /Actions }\end{array}$ & Interviewees' comments \\
\hline Suppliers (stakeholders) & $\begin{array}{l}\text { Overcome - Work with suppliers } \\
\text { to engage them in LCO practices } \\
\text { through workshops, meetings, and } \\
\text { training. Working together towards } \\
\text { finding a solution where it is } \\
\text { feasible to adopt the practice. }\end{array}$ & $\begin{array}{c}\text { "We have an annual meeting with } \\
\text { suppliers on environmental } \\
\text { themes [...]. It is like a } \\
\text { sustainability workshop [...]. So } \\
\text { we're starting to infect the chain } \\
\text { in order to understand the } \\
\text { importance of socio- } \\
\text { environmental issues for the } \\
\text { business" (Interviewee } \mathrm{N} \text { ) }\end{array}$ \\
\hline Government (stakeholders) & Accept the barrier & $\begin{array}{l}\text { Due to a lack of infrastructure in } \\
\text { the country to support a less } \\
\text { carbon-emitting mode of } \\
\text { transport, or of defined legislation } \\
\text { to contribute to organizational } \\
\text { strategies (Interviewee D) } \\
\text { Reluctance of some governmental } \\
\text { actors to support LCO because of } \\
\text { vested interest in the old economy } \\
\text { (Interviewee X). }\end{array}$ \\
\hline Clients (stakeholders) & Accept the barrier & $\begin{array}{l}\text { Clients who do not encourage or } \\
\text { plainly oppose the practice of low- } \\
\text { carbon products (i.e. Interviewee } \\
\text { C and Interviewee V) }\end{array}$ \\
\hline $\begin{array}{l}\text { Employees' attitude } \\
\text { (resource) }\end{array}$ & $\begin{array}{l}\text { Overcome - Improve employees' } \\
\text { awareness and training to change } \\
\text { the behavior of employees and } \\
\text { sensitize them to environmental } \\
\text { issues }\end{array}$ & $\begin{array}{l}\text { Company Z employed consultants } \\
\text { as LCO coaches } \\
\text { "The project, as it comes with } \\
\text { high leadership guidance at some } \\
\text { point everybody ends up } \\
\text { convinced, there's not much to be } \\
\text { done. It's top-down" (Interviewee } \\
\text { C) }\end{array}$ \\
\hline
\end{tabular}

Table 9 - Mechanisms of responses to drivers for LCO practices adoption.

\begin{tabular}{|l|l|l} 
Source of Driver & Mechanisms of Response /Actions & Interviewees' comments
\end{tabular}




\begin{tabular}{|c|c|c|}
\hline $\begin{array}{l}\text { Shareholders and owners } \\
\text { (stakeholders) }\end{array}$ & $\begin{array}{l}\text { Explore - Definition of goals, } \\
\text { participation in profits, results and } \\
\text { bonuses }\end{array}$ & $\begin{array}{l}\text { "With the company's policy focused on } \\
\text { the topic - and so the guidelines and } \\
\text { principles of company - all areas of the } \\
\text { company must have their thoughts } \\
\text { directed to environmental issues" } \\
\text { (Interviewee J). } \\
\text { "You have to include all the interested } \\
\text { ones, I can't only have the company's } \\
\text { point of view on the impact or even what } \\
\text { I can contribute, we have to take the } \\
\text { vision of the company's shareholders, } \\
\text { employees, society, consumer, of the } \\
\text { competitors, academy, communication } \\
\text { personnel, politicians, etc." (Interviewee } \\
\text { F). } \\
\text { "Profit sharing is divided into three } \\
\text { stages: we have the performance of the } \\
\text { factory as a whole in relation to the } \\
\text { goals - including the environmental } \\
\text { goals; the sector's participation, how is } \\
\text { the performance of the sector; and your } \\
\text { personal performance (Interviewed E). }\end{array}$ \\
\hline $\begin{array}{l}\text { Social and environmental } \\
\text { responsibility (capabilities) }\end{array}$ & $\begin{array}{l}\text { Explore - Alignment of sustainability } \\
\text { issues/LCO with organizations' } \\
\text { strategy }\end{array}$ & $\begin{array}{l}\text { "Regardless of the financial gain, it } \\
\text { [company J] will implement because it } \\
\text { knows it has a larger gain in the future, } \\
\text { much bigger than the financial gain" } \\
\text { (Interviewee J). } \\
\text { "The social and environmental context of } \\
\text { the development is incorporated into our } \\
\text { business strategy; it is to bring the socio- } \\
\text { environmental to the center of the } \\
\text { business [...]. It's got to have a face, an } \\
\text { identity, bringing results" (Interviewee } \\
\text { G). }\end{array}$ \\
\hline $\begin{array}{l}\text { Competitive advantage } \\
\text { (capabilities) }\end{array}$ & $\begin{array}{l}\text { Improve -monitor the adoption of } \\
\text { LCO practices through audits and } \\
\text { inspections. It helps to identify } \\
\text { improvements in LCO processes, } \\
\text { improving their features and } \\
\text { capabilities for their adoption }\end{array}$ & $\begin{array}{l}\text { 'The audits really help us to identify } \\
\text { potential and actual mistakes. It } \\
\text { increases our responsibility, but also the } \\
\text { commitment, and motivation of } \\
\text { employees to improve' (Interviewee B) } \\
\text { "[Our] R\&D Identifies best practice and } \\
\text { develop products and solutions for } \\
\text { production and logistics processes that } \\
\text { respond to the requirements of our } \\
\text { clients". }\end{array}$ \\
\hline
\end{tabular}




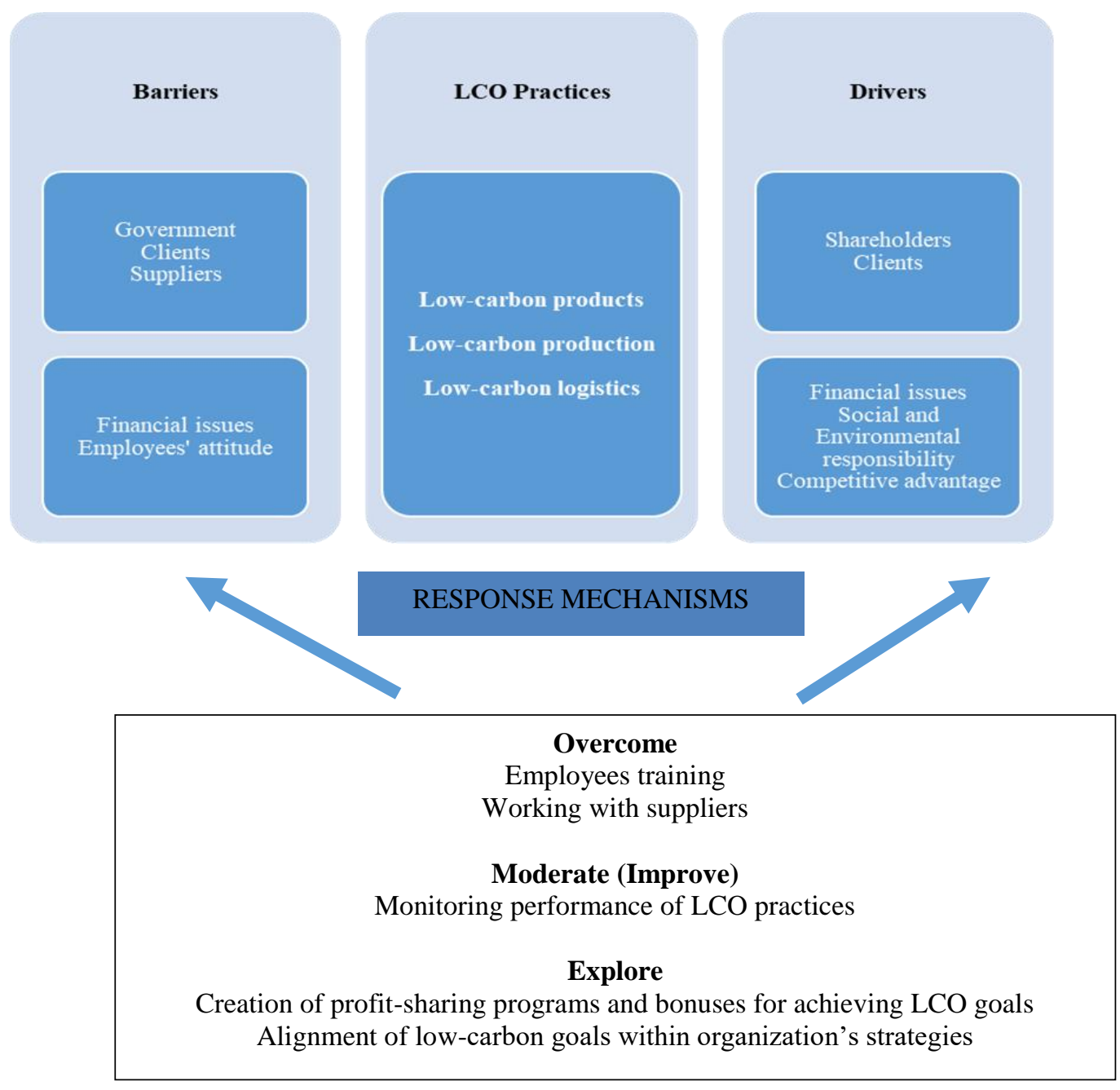

Figure 2: The main findings of the research. 
Figure 3: Proposed framework.

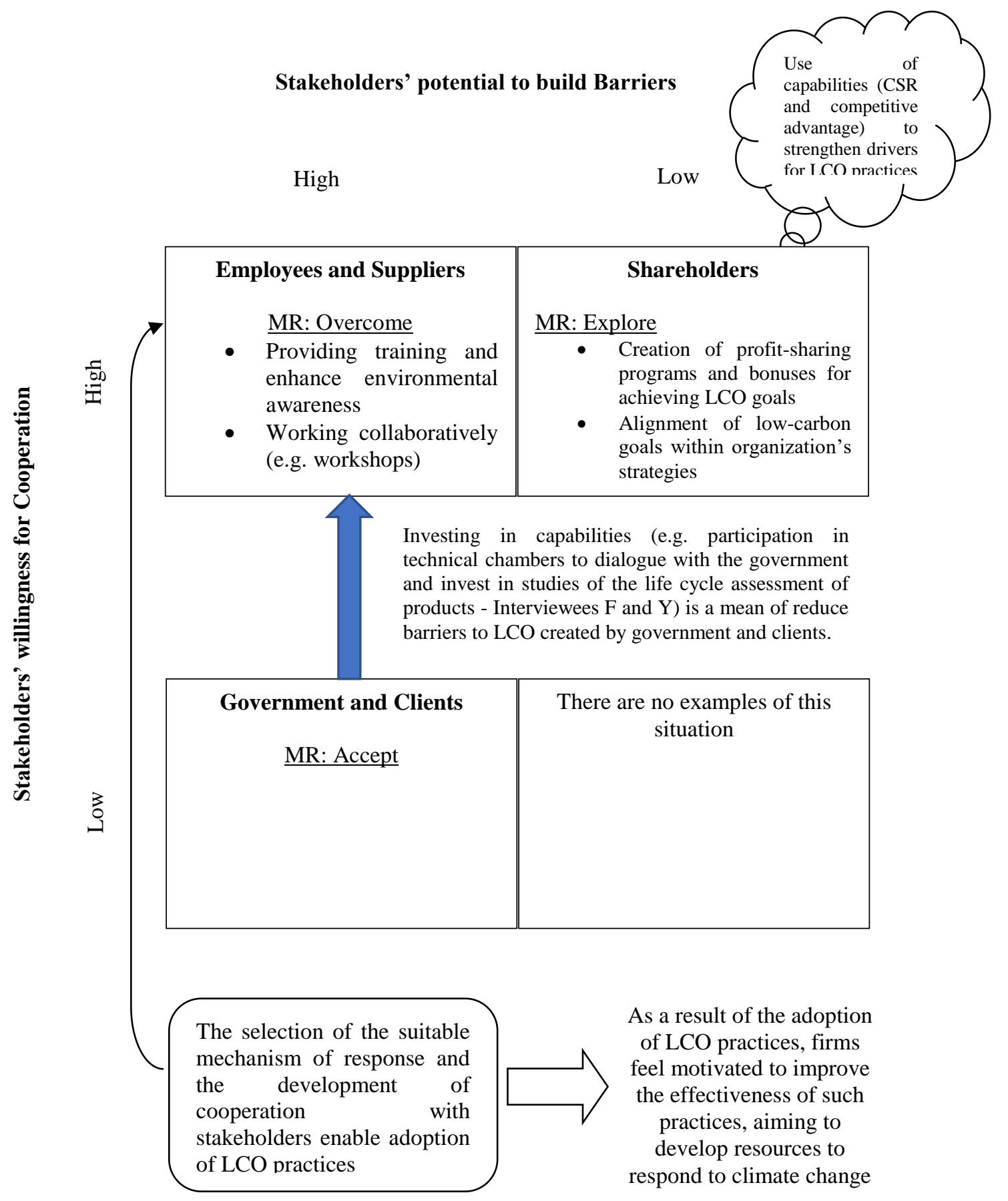




\section{APPENDIX}

\section{Script of interviews}

Group I - Low-carbon Products

1) Does the company have programs and/or policies regarding low-carbon products? How and when did the company initiate such policies and/or programs? 2) What are the practices adopted by the organization regarding low-carbon products?

3) Was there any motivation for adopting low-carbon product practices? If so, what was it? How did such motivations encourage the adoption of these practices? 4) How did the company deal with each motivation? 5) Were there any low-carbon product practices that the company wanted to adopt but didn't? What were the reasons for not adopting them? 6) Were there barriers to adopting low-carbon product practices? If so, what were they? How have barriers prevented the adoption of these practices? 7) How did the company deal with each barrier?

\section{Group II - Low-carbon Processes}

1) Does the company have programs and/or policies regarding low-carbon processes? How and when did the company initiate such policies and/or programs? 2) What are the practices adopted by the organization regarding low-carbon processes?

3) Was there any motivation for adopting low-carbon processes practices? If so, what was it? How did such motivations encourage the adoption of these practices? 4) How did the company deal with each motivation? 5) Were there any low-carbon processes practices that the company wanted to adopt but didn't? What were the reasons for not adopting them? 6) Were there barriers to adopting low-carbon processes practices? If so, what were they? How have barriers prevented the adoption of these practices? 7) How did the company deal with each barrier?

Group III - Low-carbon Logistics

1) Does the company have programs and/or policies regarding low-carbon logistics? How and when did the company initiate such policies and/or programs? 2) What are the practices adopted by the organization regarding low-carbon logistics?

3) Was there any motivation for adopting low-carbon logistics practices? If so, what was it? How did such motivations encourage the adoption of these practices? 4) How did the company deal with each motivation? 5) Were there any low-carbon logistics practices that the company wanted to adopt but didn't? What were the reasons for not adopting them? 6) Were there barriers to adopting low-carbon logistics practices? If so, what were they? How have barriers prevented the adoption of these practices? 7) How did the company deal with each barrier? 